\title{
Counseling the Prohibition of Forest Burning in Sebang Pinang Village Under the Forestry Law
}

\author{
Andi Kusumayanti ${ }^{1}$,Satriawati ${ }^{2}$, Nur Yuliany ${ }^{3}$, Irman $\mathrm{R}^{4}$, Fitriani Nur ${ }^{5}$, Eka Fitriana $\mathrm{HS}^{6}$, Andi Ika \\ Prasasti Abrar $^{7}$, Muh. Khaedar ${ }^{8}$, Nidya Nina Ichiana ${ }^{9}$, Munawarah ${ }^{10}$ \\ \{andi.kusumayanti@uin-alauddin.ac.id ${ }^{1}$, satriawati.01@gmail.com² ${ }^{2}$ nur.yuliany@uin-alauddin.ac.id ${ }^{3}$, \\ irmanrahim88@gmail.com ${ }^{4}$, fitrianinur@uin-alauddin.ac.id ${ }^{5}$, ekafitriana88@gmail.com ${ }^{6}$, \\ andiika.prasastiabrar@uin-alauddin.ac.id ${ }^{7}$, khaedarmuh@yahoo.co.id ${ }^{8}$, nidya.ninaichiana@uin- \\ alauddin.ac.id ${ }^{9}$, munawarahr@gmail.com $\left.{ }^{10}\right\}$ \\ 1,3,5,7,9 Universitas Islam Negeri Alauddin Makassar, Indonesia \\ 2,4,6,8 Universitas Mega Rezky, Indonesia \\ ${ }^{10}$ IAIN Bone, Indonesia
}

\begin{abstract}
This research used qualitative descriptive with a phenomenological approach that aimed to describe how teachers' ability of elementary school in creating and using learning media based on e-learning and m-learning. This research was conducted in District of Parigi, Gowa Regency. This place or area is one of area not far from capital of South Sulawesi. The subjects chosen in this research were teachers in SD District of Parigi, Gowa Regency. Data collection techniques used observation, interviews, questionnaires, and documentations. The instruments used questionnaires about the teachers' ability to create and to use e-learning, m-learning, and local culture-based on learning media. Data analysis technique carried out was descriptive analysis and quantitative analysis. The results of research showed that 1) the teachers' ability to create e-learning, m-learning and local culture-based learning media was still low, 2) most teachers have used learning media but they had not been combined with local culture around area and only use learning media conventionally, 3) teachers did not understand how to create e-learning and m-learning based learning media 4) inadequate facilities and infrastructure needs 5) it needs to facilitate teachers in various regions, especially remote or suburban areas by providing training in creating and using e-learning, m-learning and local culture-based learning media as a provision in educating students to face the industrial revolution 4.0.
\end{abstract}

Keywords: the ability in creating media, e-learning, m-learning, local culture.

\section{Introduction}

Education in the 21 st century has faced the industrial revolution era 4.0 now which teachers and students must develop skills immediately that can support their lives in the future. It must be needed an institution to develop the much needed skills that can facilitate children's learning processes in an organized manner. School is one of the formal education institutions that can facilitate students' learning in the classroom. The learning is expected to be a bridge to the realization of high-quality human resources and beneficial to their environment, nation and country process in the school. One of the factors that greatly influence the students' skills development is the management skills of teachers in the classroom. Teachers are very 
dominant and important factor in formal education in general for students, teachers are often used as a good example (Niarsa, 2013).

As a teacher, to educate the students with having various characteristics is not easy thing, and also development of times in industrial revolution era 4.0 currently requires teachers to face students with the predicate of millennial generation who are very familiar with the digital world. It requires teachers to immediately improve themselves by upgrading their performance in the classroom. Therefore, to face the students with the designation of the millennial generation in the era of education 4.0 , it is needed teachers 4.0 that can balance the students' development especially in Indonesia today by utilizing digital technology. One of digital uses to apply e-learning based learning media that is not limited to space and time, anytime and anywhere in the classroom. In addition e-learning is also present m-learning or what is known as mobile learning now.

The characteristics of e-learning and m-learning that are in accordance with the students' current conditions should be able to be utilized by the teachers to increase students ' motivation and interest in learning. Even though, it is known that students' motivation and interest in learning is still low, and plays a role in determining the development or lack of students' skills as well as interest in learning. Motivation and interest are very influential on students' learning outcomes. Pratiwi (2018) states that motivation has close relationship with students' interest, it will be more optimal, if there is motivation and more precise motivation given, the learning interest will also be more successful. Therefore, if motivation and students' interest in learning are low then it will certainly have an impact on students' learning achievement, they have low motivation and interest and also they have low learning outcomes.

These cases are reinforced by Indonesia's 2015 competency result released by PISA mentioned that although the three competency achievements of Indonesian students have increased from 2012 to 2015, the fact is still low level based on the average of OECD (Tohir, 2016). One of the causes that students' low achievement of the competencies possessed by students is inappropriate methods and media used by teachers as well as the use of ICTs which are rarely used even though ICT and students are two things that cannot be separated each other because these two things are created at the same time, so the students who are used to digital feel bored and saturated with the learning process that occurs in the classroom.

Based on the observations result had been conducted in MI Batumenteng, Parigi SubDistrict, Gowa Regency, it was found that the students' average achievement competencies were still very low. There are some findings obtained relating to the students' low learning achievement in the field namely1) the teacher has not been able to manage the class well, 2) the monotonous of teaching and learning process causes students feel bored, 3) inadequate facilities, 4) students' motivation and learning interests are low) 3) students do not pay attention to the teacher's direction well, 5) the teacher does not recognize the characteristics of his/her students, 6) the teacher does not use media that is relevant to the characteristics of his/her students, 7) the teacher simply performs tasks and ignores the increase of students' achievement, 8) The use of conventional learning media is very rare especially e-learning, mlearning, and local culture 9) the teacher is unable to make online-based learning media.

Based on several facts are explained above, it is known that poorly learning conditions of students require teachers to $\mathrm{i}$ innovate learning immediately in the classroom by paying attention to the students "characteristics who are in accordance with current education 4.0. Therefore, learning based e-learning and m-learning are one solution that is indeed very relevant to 4.0 education because it is closely related to information and communication technology (ICT) literacy which has become an absolute obligation for current 4.0 teachers. Government Regulation of the Republic of Indonesia Number 74 of 2008 article three verse 
four about teachers says that pedagogic competence that must be mastered by teachers namely the use of technology. Mulyasa (2009) states that competence is a combination of knowledge, skills, values and attitudes reflected in habits of thinking and acting.

The use of e-learning can simplify teachers in explaining materials that he/she wants to explain in the classroom. In addition, the use of e-learning can also streamline students' learning time in the class because it no longer explains conventionally with manual learning devices so that the costs needed will also be more economical. This case is the same with Rohmah (2016) who stated that there are four benefits of the implementation of e-learning, namely 1) it can shorten the time and cost of study more economically, 2) facilitate interaction between students and materials, 3) students can share information and access learning materials at any time and repeatedly, 4) the process of developing knowledge is not only in the classroom but help computer equipment and networks, students can be actively involved in teaching-learning process. Not much different from e-learning the use of m-learning in the classroom also provides many conveniences, one of which is that students can easily learn to use hand phones that they can use whenever and wherever.

When the teachers understand ICT literacy well, they can hold contextual learning easily based on local culture. Local culture-based learning is learning that also requires teachers to be able to develop their teaching skills, therefore, they are also increasingly able to balance the characteristics of students in the current era of education 4.0. Thus, Teacher 4.0 should also be able to create e-learning based learning media, m-learning, and local culture in order to achieve predetermined learning goals. Based on these cases, it needs to be an effort to find out how the teachers' ability to make e-learning, m-learning and local culture-based learning media as a bridge in developing learning students' achievement. So that, the writers assume that the topic in accordance with the facts described above is "The Analysis of Teachers' Ability in Creating Learning Media Based on E-Learning, M-Learning and Local Culture at District of Parigi, Gowa Regency"

\section{Method}

The main text should be written using Times New Roman, 10pt, fully justified. Italics can be used for emphasis and bold typeset should be avoided.

Method used in this research was qualitative descriptive with a phenomenological approach that aimed to observe how teachers' ability of elementary school in creating and using learning media based on e-learning and m-learning. This research was conducted in District of Parigi, Gowa Regency. This place or area is one of area not far from capital of South Sulawesi.

The numbers of population in this research were all teachers in MI Batumenteng of Parigi District, Gowa Regency. Sugiyono (2008) stated that population was a generalization area consisting of subjects that have certain qualities and determined by researchers to be studied and then made conclusion. The subjects chosen in this research were as many as 5 teachers at MI Batumenteng. Data collection techniques used observation, interviews, questionnaires, and documentations. The instruments used questionnaires about the teachers' ability to create and to use e-learning, m-learning, and local culture-based on learning media. Data analysis technique carried out was descriptive analysis which is described in the form of diagrams and quantitative analysis was obtained from the results of the questionnaire. Questionnaire about the ability to create and to use learning media based on e-learning, m-learning, and local culture in the form of a checklist and using a Likert scale. The questionnaire organizers consisted of very high, high, medium, low, very low. The number of questionnaire items each was 16 statements so that the ideal score and ideal average are: 


$$
\begin{gathered}
\mathrm{MI}=\frac{16+80}{2}=48 \\
\mathrm{SI}=\frac{80-16}{6}=10,67 .
\end{gathered}
$$

Table 1. Categorization Questionnaire

\begin{tabular}{lcl}
\hline \multicolumn{1}{c}{ Interval } & Interval Score & \multicolumn{1}{c}{ Criteria } \\
\hline $\mathbf{M i}+\mathbf{1}, \mathbf{5 S i}<\mathbf{X} \leq \mathbf{M i}+\mathbf{3 S i}$ & $64<\mathrm{X} \leq 80$ & Very High \\
$\mathbf{M i}+\mathbf{0} \mathbf{5 S i}<\mathbf{X} \leq \mathbf{M i}+\mathbf{1 , 5 S i}$ & $53.33<\mathrm{X} \leq 64$ & High \\
$\mathbf{M i}-\mathbf{0 , 5 S i}<\mathbf{X} \leq \mathbf{M i}+\mathbf{0 , 5 S i}$ & $42.67<\mathrm{X} \leq 53.33$ & Medium \\
$\mathbf{M i}-\mathbf{1}, \mathbf{5 S i}<\mathbf{X} \leq \mathbf{M i}-\mathbf{0 , 5 S i}$ & $32<\mathrm{X} \leq 42.67$ & Low \\
$\mathbf{M i}-\mathbf{3 S i} \leq \mathbf{X} \leq \mathbf{M i}-\mathbf{1 , 5 S i}$ & $16 \leq \mathrm{X} \leq 32$ & Very Low \\
\hline
\end{tabular}

(Azwar, 2014: 148)

Keterangan:
X : Total of Actual Score
Mi : 1/2 (Ideal Maximum Score + Ideal Minimum Score)
$\mathrm{Si}$ : 1/6 (Ideal Maximum Score - Ideal Minimum Score)

\section{Result and Discussion}

\section{a) Result}

Based on the results of the research that had been carried out by researchers, it was found that several answers related to the predetermined research objectives and their relevance to the circumstances that exist in the field. This research was conducted during 3 days by giving questionnaires in the form of statements related to teachers' ability to make and to use learning media based on e-learning, m-learning, and local culture.

1) The ability to create learning media based on E-learning, M-learning, and local culture

After the research was conducted measurements related to the learning media questionnaire. Data were analyzed by using descriptive analysis. Questionnaires description data that had been analyzed to be presented in table 2 below.

Table 2. Description of teachers' ability to make and to use learning media based on Elearning, M-learning, and local culture

\begin{tabular}{lc}
\hline \multicolumn{1}{c}{ Description } & Ability to make learning media \\
\hline Mean Score & 49.57 \\
\hline Standard deviation & 4.541 \\
\hline Maximum score of theoretic & 80.00 \\
\hline Minimum score of theoretic & 16.00 \\
\hline Maximum score & 57.00 \\
\hline Minimum score & 44.00 \\
\hline
\end{tabular}

Based on the results of descriptive analysis table 2 above, it was to be seen that maximum score obtained from the teachers' ability to create learning media was 57 while minimum score was 44 with a standard deviation of 4,541 
2) The ability to create learning media based on E-learning, M-learning, and local culture After the research was carried out measurements related to learning media questionnaire. Data were analyzed by using descriptive analysis. questionnaire description data that had been analyzed was presented in table 3 below.

Table 3. Description of Ability to Use Learning Media Based on E-learning, M-learning, and Local Culture

\begin{tabular}{lc}
\hline \multicolumn{1}{c}{ Description } & Ability to make learning media \\
\hline Mean Score & 50.71 \\
\hline Standard deviation & 3.684 \\
\hline Maximum score of theoretic & 80.00 \\
\hline Minimum score of theoretic & 16.00 \\
\hline Maximum score & 58.00 \\
\hline Minimum score & 47.00 \\
\hline
\end{tabular}

Based on the results of descriptive analysis table 3 above, it can be seen that the maximum score was obtained from the teachers' ability to create learning media was 58 while the minimum score was 47 and the standard deviation was 3.684

\section{b) Discussion}

Based on the results of a predetermined questionnaire calculation, it can be seen that the results of the determination of the questionnaire categorizing the teachers' ability to create elearning, m-learning, and local culture learning media were still medium category. Here are table of implementation.

Table 4 Determination of the categorization of the ability to create learning media

\begin{tabular}{cllll}
\hline Respondent & $\begin{array}{l}\text { Ability Score in } \\
\text { making learning } \\
\text { media }\end{array}$ & Category & $\begin{array}{l}\text { Ability Score in using } \\
\text { learning media }\end{array}$ & Category \\
\hline G1 & 52 & Medium & 51 & Medium \\
G2 & 50 & Medium & 51 & Medium \\
G3 & 52 & Medium & 47 & Medium \\
G4 & 46 & Medium & 50 & Medium \\
G5 & 46 & Medium & 51 & Medium \\
G6 & 57 & High & 58 & High \\
G7 & 44 & Medium & 47 & Medium \\
Mean Score & 49.57 & Medium & 50.71 & Medium \\
\hline
\end{tabular}

So, the results of research by observing and filling in questionnaires related to the teachers' ability to create e-learning, m-learning and local culture-based on learning media where they answered the number of statements in this stage and almost all them responded with moderate scores with an average score was 49.57. Most of the teachers were not able to create e-learning and m-learning based on learning media and it was still very rare to associate the material that 
they teach with the local culture in their school. In addition, based on the results of interviews, the lack of available facilities also caused, there was no teacher to create e-learning based on learning media. Even though the school is a school not far from the capital of province, the lack of activities that can facilitate the teachers' ability to create e-learning and m-learningbased learning media to make teachers were less able to create e-learning, m-learning, and local culture based learning media.

Meanwhile, for the teachers' ability indicator to use e-learning, m-learning, and local culture-based learning media, the results of these statements were in the medium category which was equal to 50.71. There were several facts that found the teachers felt the characteristics of the learning media were not in accordance with the students' characteristics, so that they did not conduct e-learning bases, because facilities did not support and less effective learning environment.

\section{Conclusions}

Based on the results of the research can be concluded that the teachers' ability to create and use e-learning, m-learning and local culture-based learning media in MI Menteng Batung, Parigi Subdistrict Gowa regency. Data are obtained that 1) the teachers' ability to create elearning, m-learning and culture-based learning media local is still medium category, 2) most teachers have used learning media but they have not been combined with local culture around area and only use conventional learning media, 3) teachers do not understand how to create elearning based learning media and m-learning 4) inadequate facilities and infrastructure, 5) it needs to facilitate teachers in various regions, especially remote areas or suburbs by providing training in creating and using e-learning, m-learning and local culture-based learning media in preparation for educating the students to face industrial revolution 4.0.

\section{References}

[1] Mulyasa, E. 2009. Standard for Teacher Competence and Certification. Bandung: PT Remaja Rosdakarya

[2] Arnis.: The Use of Variable Learning Media to Improve Teachers' Learning Competence in SDN 113 Pekanbaru. Vol. 3, No. 2., pp. 10-11. Journal of social science education and humanities.

[3] Niarsa, Aditya, 2013. Study of Teacher Competence in Using Information and Communication Technology-Based Learning Media in SD 01 Ledok, Sambong District, Blora Regency. State University of Semarang.

[4] Pratiwi, B. S. 2018. The Relationship between Students' Learning Motivation and Interest of Class VIII Students at SMPN 3 Depok Academic Year 2018/2019. University of PGRI Yogyakarta.

[5] Sugiyono. 2008. Research Methods for Qualitative Education, and R \& D. Bandung: Alfabeta

[6] Tohir Muhammad Has, 2016. PISA Indonesia Results 2015 having Increased. Http://www.researchgate.net/publicasetion/322420345 